\title{
Selected Bibliography
}

Alchon, Suzanne Austin. A Pest in the Land. Albuquerque: University of New Mexico Press, 2003.

Alden, Dauril. "Indian versus Black Slavery in the State of Maranhão during the Seventeenth and the Eighteenth Centuries," Bibliotheca Americana vol. 1, no. 3 (1984): 91-142.

Alencar Guzmán, Décio de. "A colonização nas Amazônias: guerras, comércio e escravidão nos séculos XVII e XVIII," Revista Estudos Amazônicos vol. 3, no. 2 (2008): 103-139.

Allen, Theodore W. The Invention of the White Race: The Origin of Racial Oppression in Anglo- America, 2 vols. New York: Verso, 1997.

Altman, Ida and James Horn. "To Make America." European Emigration in the Early Modern Period. Berkeley: University of California Press, 1991.

Amussen, Susan. An Ordered Society: Gender and Class in Early Modern England. Oxford: Basil Blackwell Ltd, 1988.

Antunes, Cátia. "Oost voor West en West voor Oost. De Nederlands-Portugese Koloniale Interactie in de Zeventiende Eeuw." In Het verre gezicht: Politieke en Culturele Relaties Tussen Nederland en Azië, Afrika en Amerika, edited by Alicia Schrikker and Thomas Lindblad, 35-38. Franeker: Van Wijnen, 2011.

Antunes, Catia, and Filipa Ribeiro da Silva. "Amsterdam Merchants in the Slave Trade and African Commerce, 1580s-1670s." Tijdschrift Voor Sociale En Economische Geschiedenis vol. 9, no. 2 (2012): 3-30.

Appleby, John C. "A Guinea Venture, c. 1657: A Note on the Early English Slave Trade." Mariner's Mirror vol. 79, no. 1 (1993): 84-87.

Arana, Luis. Defenses and Defenders at St. Augustine. St. Augustine: St. Augustine Historical Society, 1999.

Arenz, Karl-Heinz. De l'Alzette à l'Amazonie: Jean-Philippe Bettendorff et les jésuites en Amazonie portugaise (1661-1693). Saarbrücken:Éditions universitaires européennes, 2010.

Armitage, David. "The Cromwellian Protectorate and the Languages of Empire," Historical Journal vol. 35, no. 3 (1992): 531-555.

- The Ideological Origins of the British Empire. New York: Cambridge University Press, 2000.

- "Three Concepts of Atlantic History." In The British Atlantic World, 1500-1800, edited by David Armitage and Michael Braddick, 13-32. New York: Palgrave MacMillan, 2002.

Arnade, Charles W. The Siege of St. Augustine in 1702. Gainesville: University Press of Florida, 1959 . 
Arrighi, Giovanni. The Long Twentieth Century. Money, Power, and the Origins of Our

Times. London/New York: Verso, 2010.

Arrighi, Giovanni and Beverly Silver. Chaos and Governance in the Modern World System. Minneapolis, MN: University of Minnesota, 1999.

Aylmer, G.E. The Levellers in the English Revolution. Ithaca, NY: Cornell University Press, 1975 .

Bailyn, Bernard. Atlantic History: Concept and Contours. Cambridge, MA: Harvard University Press, 2005.

Bangou, Henri. La Guadeloupe: Les Aspects de la Colonisation, 1848-1939. Paris: Harmattan, 1987.

Barcia, Manuel. Seeds of Insurrection: Domination and Resistance on Western Cuban Plantations, 1808-1848. Baton Rouge: Louisiana State University Press, 2008.

Barrio Gozalo, Maximiliano. "La esclavitud en el Mediterráneo occidental en el siglo XVIII. Los esclavos del rey en España," Critica storica vol. 17, no. 2 (1980): 199-256.

- Esclavos y cautivos. Conflicto entre la Cristianidad y el Islam en el Siglo XVIII. Valladolid: Junta de Castilla y León, 2006.

Baucom, Ian. Specters of the Atlantic: Finance Capital, Slavery, and the Philosophy of History. Durham, NC: Duke University Press, 2005.

Beckles, Hilary. White Servitude and Black Slavery in Barbados, 1627-1715. Knoxville: University of Tennessee Press, 1989.

"A 'Riotous and Unruly Lot': Irish Indentured Servants and Freemen in the English West Indies, 1644-1713." William and Mary Quarterly vol. 47, no. 4 (1990): $515^{-521 .}$

- "The Colours of Property: Brown, White and Black Chattels and Their Responses on the Caribbean Frontier." In Unfree Labour in the Development of the Atlantic World, edited by Paul Lovejoy and Nicholas Rogers, 36-51. London: Frank Cass, 1994.

- "The Concept of "White Slavery in the English Caribbean During the Early Seventeenth Century." In Early Modern Conceptions of Property, edited by John Brewer and Susan Staves, 572-584. London: Routledge, 1996.

—. "Capitalism, Slavery and Caribbean Modernity," Callaloo vol. 20, no. 4 (1997): $777-789$.

- Great House Rules: Landless Emancipation and Workers' Protest in Barbados, 1838-1938. Kingston, JA: Ian Randle, 2004.

Beier, A.L. Masterless Men: The Vagrancy Problem in England 1560-1640. London: Methuen, 1985 .

Benton, Lauren. "From the World-Systems Perspective to Institutional World History: Culture and Economy in Global Theory." Journal of World History vol. 7, no. 2 (1996): 261-295.

- Law and Colonial Cultures: Legal Regimes in World History, 1400-1900. New York:

Cambridge University Press, 2001. 
Bettendorff, João Felipe SJ, Crônica da missão dos Padres da Companhia de Jesus no Maranhão. Belém: SECULT, 1990 [1698].

Betts, Raymond. Assimilation and Association in French Colonial Theory, 1890-1914. Lincoln: University of Nebraska Press: 2005 [1960].

Bhandari, Rakesh. "Slavery and Wage Labor in History." Rethinking Marxism vol. 19 (2007): 396-408.

Billings, Warren M. "The Law of Servants and Slaves in Seventeenth-Century Virginia." Virginia Magazine of History and Biography vol. 99 (1991): 45-62.

Bliss, Robert M. Revolution and Empire: English Politics and the American Colonies in the Seventeenth Century. Manchester: Manchester University Press, 1990.

Bolland, O. Nigel "Colonization and Slavery in Central America," In Unfree Labour in the Development of the Atlantic World, edited by Paul E. Lovejoy and Nicholas Rogers, 11-25. Ilford UK and Portland OR: Frank Cass, 1994.

Bonke, Hans, and Katja Bossaers. Heren investeren. De bewindhebbers van de WestFriese Kamers van de VOC. Haarlem: Regionale Geschiedbeoefening Noord-Holland, 2002.

Boulton, Jeremy. "The Poor Among the Rich: Paupers and the Parish in the West End, 1600-1724." In Londinopolis: Essays in the Cultural and Social History of Early Modern London, edited by Paul Griffiths and Mark S.R. Jenner, 197-225. Manchester: Manchester University Press, 2000.

Boxer, C.R. The Dutch in Brazil, 1624-1654. Oxford: Clarendon Press, 1957.

Boyd-Bowman, Peter. Indice geobiográfico de cuarenta mil pobladores españoles de América en el Siglo SVI, vol. I, 1493-1519. Bogotá: Instituto de Caro y Cuervo, 1964 .

-_- Indice de cuarenta mil pobladores españoles de América en el Siglo SVI, vol. II, 1520-1539. Mexico: Ed. Jus. Academia Mexicana de Genealogía y Heráldica, 1968.

Brailsford, H.N. The Levellers and the English Revolution [edited and prepared by Christopher Hill]. London: Cresset Press, 1961.

Brandon, Pepijn. "Global Power, Local Connections: The Dutch Admiralties and their Supply Networks." In The Contractor State and its Implications, 1659-1815, edited by Richard Harding and Sergio Solbes Ferri, 57-80. Las Palmas de Gran Canaria: Universidad de Las Palmas de Gran Canaria, Servicio de Publicaciones, 2012.

- Masters of War. State, Capital, and Military Enterprise in the Dutch Cycle of Accumulation, 16oo-1795. Leiden/Boston: Brill, 2014.

Braudel, Ferdinand. Civilization and Capitalism, 15th-18th Centuries, 3 vols., translated by Miriam Kochan. Berkeley, CA: University of California Press, 1992.

- The Mediterranean and the Mediterranean World in the Age of Phillip II, 2 vols., translated by Siân Reynolds, Berkeley, CA: University of California Press, 1995.

Brenner, Robert. "The Origins of Capitalist Development: A Critique of Neo-Smithian Marxism." New Left Review vol. 104 (1977): 25-92. 
Brunsman, Denver. The Evil Necessity: British Naval Impressment in the EighteenthCentury Atlantic World. Charlottesville: University of Virginia Press, 2013.

Buffon, Alain. Monnaie et Crédit en Economie Coloniale: Contribution à l'Histoire économique de la Guadeloupe, 1635-1919. Basse-Terre: Société d'Histoire de la Guadeloupe, 1979 .

Burke, Peter The French Historical Revolution: The Annales School 1929-1989. Stanford: Stanford University Press, 1990.

Bushnell, Amy Turner. Situado and Sabana: Spain's Support System for the Presidio and Mission Provinces of Florida. New York: American Museum of Natural History, 1994. Butel, Paul. Histoire des Antilles Françaises XVII-XXe Siècles. Paris: Perrin, 2002.

Buve, R. "Gouverneur Johannes Heinsius, de Rol van Van Aerssens Voorganger Tijdens de Surinaams-Indische Oorlog, 1678-1680." Nieuwe West-Indische Gids vol. 45 (1966): 14-26.

Callaghan, Sean. To Hell or Barbados. Dingle: Brandon Books, 2001.

Cañizares-Esquerra, Jorge. "Some Caveats about the 'Atlantic Paradigm." History Compass vol. 1, no. 1 (2003): 1-4.

Cañizares-Esguerra, Jose and Erik Seeman, eds., The Atlantic in Global History, 1500200o. Upper Saddle River, NJ: Pearson, 2007.

Canny, Nicholas. "Writing Early Modern History: Ireland, Britain, and the Wider World." The Historical Journal vol. 46, no. 3 (2003): 723-747.

Canny, Nicholas and Anthony Pagden, eds. Colonial Identity in the Atlantic World, $1500-$ 180o. Princeton: Princeton University Press, 1989.

Canny, Nicholas and Karen Ordahl Kupperman. "The Scholarship and Legacy of David Beers Quinn, 1909-2002." William and Mary Quarterly vol. 6o, no. 4 (2003): 843-86o.

Capp, Bernard. Cromwell's Navy: The Fleet and the English Revolution 1648-1660. London: Clarendon Press, 1989.

Carlton, Charles. Going to the Wars: The Experience of the British Civil Wars, 1638-1651. New York: Routledge, 1994.

Carneiro da Cunha, Manuela. "Introdução a uma história indígena." In História dos índios no Brasil, edited by Manuela Carneiro da Cunha, 9-24. São Paulo: Companhia das Letras, 1992.

César, José Vicente. "Situação legal do índio durante o período colonial (1500-1822)," América Indígena vol. 45, no. 2 (1985): 391-425.

Chambouleyron, Rafael. “Duplicados clamores'. Queixas e rebeliões na Amazônia colonial (século XVII)," Projeto História vol. 33 (2006): 159-78.

Chambouleyron, Rafael and Fernanda Bombardi, "Descimentos privados de índios na Amazônia colonial (séculos XVII e XVIII)," Varia Historia vol. 27, no. 46 (2011): 601-23.

Chambouleyron, Rafael, Fernanda Aires Bombardi, and Vanice Siqueira de Melo, "O 'estrondo das armas': violência, guerra e trabalho indígena na Amazônia colonial," Projeto História vol. 39 (2009): 115-37. 
Chaplin, Joyce E. "Expansion and Exceptionalism in Early American History." Journal of American History vol. 89, no. 4 (2003): 1431-1155.

—. "The Atlantic Ocean and its Contemporary Meanings, 1492-1808." In Atlantic History: A Critical Appraisal, edited by Jack Greene and Phillip Morgan. New York: Oxford University Press, 2009.

Childs, Matt D. The Aponte Rebellion in Cuba and the Struggle against Atlantic Slavery. Chapel Hill: University of North Carolina Press, 2006.

Christopher, Emma, Cassandra Pybus, and Marcus Rediker. Many Middle Passages: Forced Migration and the Making of the Modern World. Berkeley: University of California Press, 2007.

Coelho Cabral, Maria do Socorro. Caminhos do gado: conquista e ocupação do sul do Maranhão. São Luís, SIOGE, 1992.

Cohen, William. The French Encounter with Africans: White Responses to Blacks, 1530-1880. Bloomington: Indiana University Press, 1980.

Coldham, Peter Wilson. Emigrants in Chains: A Social History of Forced Emigration to the Americas of Felons, Destitute Children, Political and Religious Non-Conformists, Vagabonds, Beggars and Other Undesirables 1607-1776. Baltimore: Genealogical Publishing Co., 1992.

Conklin, Alice. A Mission to Civilize: The Republican Idea of Empire in France and West Africa, 1895-1930. Stanford: Stanford University Press, 1997.

Cooper, Frederick, Thomas C. Holt, and Rebecca J. Scott, Beyond Slavery: Explorations of Race, Labor and Citizenship in Post Emancipation Societies. Chapel Hill: University of North Carolina Press, 2000.

Cottias, Myriam "La Silence de la Nation: Les 'Cieilles' Colonies comme Lieu de Définition des Dogmes Républicains, 1848-1905." Outre-Mers vol. 90, nos. 338-339 (2003): 21-45.

Coutinho, Milson. A revolta de Bequimão. 2nd ed. São Luís: Instituto Geia, 2004.

Curtin, Philip. The Rise and Fall of the Plantation Complex: Essays in Atlantic History. New York: Cambridge University Press, 1998.

Curto, Jose and Paul Lovejoy, eds., Enslaving Connections: Changing Cultures of Africa and Brazil during the Era of Slavery. Amherst, NY: Humanity Books, 2004.

da Silva, Filipa Ribeiro. Dutch and Portuguese in Western Africa. Empires, Merchants and the Atlantic System, 1580-1674. Leiden/Boston: Brill, 2011.

Daniels, Christine and Michael V. Kennedy, eds., Negotiated Empires: Centers and Peripheries in the New World, 1500-1800. New York: Routledge, 2001.

Davis, David Brion. The Problem of Slavery in Western Culture. New York and Oxford: Oxford University Press, 1988 [1966].

- Inhuman Bondage: The Rise and Fall of New World Slavery. New York: Oxford University Press, 2008.

de Abreu, João Capistrano. Chapters of Brazil's Colonial History, 1500-180o, translated by Arthur Brakel. Oxford: Oxford University Press, 1997. 
de Mello, Evaldo Cabral. De Braziliaanse affaire. Portugal, de Republiek der Verenigde Nederlanden en Noord-Oost Brazilië, 1641-1669, translated by Catherine Barel. Zutphen: Walburg Pers, 2005.

de Vries, Jan. "The Dutch Atlantic Economies." In The Atlantic Economy During the Seventeenth andEighteenth Centuries: Organization, Operation, Practice, and Personnel, edited by Peter A. Coclanis, 1-29. Columbia: University of South Carolina Press, 2005 .

Deerr, Noel. The History of Sugar, Vol. 2 London: Chapman and Hall, 1949-50. den Heijer, Henk. De Geschiedenis van de WIC. Zutphen: Walburg Pers, 2002.

- Goud, Ivoor en Slaven. Scheepvaart en Handel van de Tweede Westindische Compagnie op Afrika, 1674-1740. Zutphen: Walburg Pers, 1997.

—. "Het Recht van de Sterkste in de Polder: Politieke en Economische Strijd Tussen Amsterdam en Zeeland over de Kwestie Brazilië, 1630-1654." In Harmonie in Holland. Het poldermodel van 15 oo tot nu edited by D. Bos, M.A. Ebben and Henk te Velde, 72-92. Amsterdam: Bert Bakker, 2007.

den Heijer, Henk, and Victor Enthoven, "Nederland en de Atlantische wereld, 160o1800: Een Historiografisch Overzicht." Tijdschrift voor Zeegeschiedenis vol. 24, no. 2 (2005): 147-166.

Denmark, Robert A. and Kenneth P. Thomas, "The Brenner-Wallerstein Debate." International Studies Quarterly vol. 32, no. 1 (1988): 47-65.

Diniz de Carvalho Júnior, Almir. “Índios cristãos: a conversão dos índios na Amazônia portuguesa (1653-1769)." PhD Diss., Universidade Estadual de Campinas, Campinas, 2005 .

Domínguez Ortiz, Antonio. "La esclavitud en Castilla durante la Edad Moderna." Estudios de historia social de España. Madrid: Consejo Superior de Investigaciones Científicas, $195^{2}$.

Donoghue, John. "Out of the Land of Bondage': The English Revolution and the Atlantic Origins of Abolition." American Historical Review vol. 115, no. 4 (2010): 943-974.

—. 'Fire under the Ashes': An Atlantic History of the English Revolution. Chicago: University of Chicago Press, 2013.

—. "Indentured Servitude in the Seventeenth Century Atlantic: A Brief Survey of the Literature." History Compass (2013): 1-10.

Dubois, Laurent. A Colony of Citizens: Revolution and Slave Emancipation in the French Caribbean, 1787-1804. Chapel Hill: University of North Carolina Press, 2004.

Durston, Chris. "Let Ireland be Quiet:" Opposition in England to the Cromwellian Conquest of Ireland." History Workshop Journal vol. 21 (1986): 105-112.

Eisenberg, José. As missões jesuíticas e o pensamento político moderno: encontros culturais, aventuras teóricas. Belo Horizonte: Editora da Universidade Federal de Minas Gerais, 2000. 
Elliott, J.H. Empires of the Atlantic World:Britain and Spain in America. New Haven: Yale University Press, 2006.

Eltis, David. The Rise of African Slavery in the Americas. Cambridge: Cambridge University Press, 2000.

- Coerced and Free Migration: Global Perspectives. Stanford: Stanford University Press, 2002.

Eltis, David, David Richardson, Stephen D. Behrendt and Herbert Klein, eds., The Atlantic Slave Trade: A Database on CD-ROM Set and Guide. New York: Cambridge University Press, 1999.

Eltis, David and David Richardson, eds., Extending the Frontiers: Essays on the New Transatlantic Slave Trade Database. New Haven, CT: Yale University Press, 2008.

Engerman, Stanley L. "Servants to Slaves to Servants: Contract Labour and European Expansion." In Colonialism and Migration: Indentured Labour Before and After Slavery, edited by P. Emmer, 263-294. Dordrecht: Martinus Nijhoff Publisher, 1986.

Engerman, Stanley L. and Kenneth L. Sokoloff, "Factor Endowments, Institutions, and Differential Paths of Growth Among the New World Economies: a View from Economic Historians of the United States." In How Latin America Fell Behind. Essays on the Economic Histories of Brazil and Mexico, 1800-1914, edited by Stephen Haber, 260-304. Stanford: Stanford University Press, 1997.

Enthoven, Victor. "Van Steunpilaar tot Blok aan Het Been: De Verenigde Oost-Indische Compagnie en de Unie." In De Verenigde Oost-Indische Compagnie Tussen Oorlog en Diplomatie, edited by Gerrit Knaap and Ger Teitler, 35-58. Leiden: KITLV Uitgeverij: 2002.

. "Mars en Mercurius Bijeen. De Smalle Marges van het Nederlandse Maritieme Veiligheidsbeleid Rond 1650." In In het Kielzog: Maritiem-historische Studies Aangeboden aan Jaap R. Bruijn bij Zijn Vertrek als Hoogleraar Zeegeschiedenis aan de Universiteit Leiden edited by Leo Akveld, 40-6o. Amsterdam: De Bataafse Leeuw, 2003.

—. "That Abominable Nest of Pirates': St. Eustatius and the North Americans, 1680-1780." Early American Studies: An Interdisciplinary Journal vol. 10, no. 2 (2012): 239-301.

Emmer, Pieter C. "The Dutch and the Atlantic challenge, 1600-180o." In $A$ Deus ex Machina Revisited. Atlantic Colonial Trade and European Economic Development, edited by P.C. Emmer, O. Pétré-Grenouilleau, and J.V. Roitman, 151-177. Leiden/ Boston: Brill, 2006.

Emmer, P.C., and W.W. Klooster. "The Dutch Atlantic, 1600-180o: Expansion without Empire." Itinerario vol. 23, no. 2 (1999): 48-69.

Estrade, Paul. "Los colonos como sustitutos de los esclavos negros." In Cuba la perla de las Antillas: Actas de las I Jornadas sobre 'Cuba y su historia,' edited by Consuelo Naranjo Orovio and Tomás Mallo Gutiérrez, 93-107. Madrid: Dos Calles, 1994. 
Fallope, Josette. Esclaves et Citoyens: Les Noirs à la Guadeloupe au XIXe Siècle dans les Processus de Résistance et d'Intégration, 1802-1910. Basse-Terre: Société d'Histoire de la Guadeloupe, 1992.

Farnell J.E. "The Navigation Act of 1651, the First Dutch War, and the London Merchant Community." Economic History Review vol. 16, no. 3 (1964): 439-45.

Fatah-Black, Karwan. "Suriname and the Atlantic World, 1650-180o." Ph.D. thesis: Leiden University, 2013.

Fernandez-Armesto, Felipe. The Americas: A Hemispheric History. New York: Modern Library, 2003.

Fink, Leon, ed. Workers Across the Americas: The Transnational Turn in Labor History. New York: Oxford University Press, 2011.

Finn, Margot. The Character of Credit: Personal Debt in English Culture, 1740-1914. New York: Cambridge University Press, 2003.

Fitzmaurice, Andrew. "The Civic Solution to the Crisis of English Colonization, 16091625." The Historical Journal, vol. 42, no. 1 (1999): 25-51.

Flory, Céline. "New Africans in Post-Slavery French West Indies and Guiana, 1854-1889." In Paths of the Atlantic Slave Trade: Interactions, Identities, and Images, edited by Ana Lucia Araujo. Amherst, MA: Cambria, 2011.

Fry, Bruce W. "An Appearance of Strength": the Fortifications of Louisbourg. 2 vols. Ontario: Parks Canada, 1984.

Frykman, Niklas. "Seamen on Late Eighteenth Century Warships," International Review of Social History vol. 54 (2009): 67-93.

Fumerton, Patricia. Unsettled: The Culture of Mobility and the Working Poor in Early Modern England. Chicago: University of Chicago Press, 2006.

Gaastra, Femme. Bewind en Beleid bij de VOC: De Financiële en Commerciële Politiekvan de Bewindhebbers, 1672-1702. Zutphen: Walburg Pers, 1989.

Galenson, David. White Servitude in Colonial America: An Economic Analysis. Cambridge: Cambridge University Press, 1981.

- "The Rise and Fall of Indentured Servitude in the Americas," Journal of Economic History vol. 44, no. 1 (1984): 1-26.

Galloway, J.H. The Sugar Cane Industry: An Historical Geography from its Origins to 1914. Cambridge: Cambridge University Press, 1989.

Games, Alison. "Migration." In The British Atlantic World, 1500-180o, edited by David Armitage and Michael Braddick, 33-52. New York: Palgrave, 2002.

- The Web of Empire: English Cosmopolitans in an Age of Empire. New York: Oxford University Press, 2008.

Games, Alison, Phil Stern, Paul Mapp, Peter Colcanis, and Julie Sievers, "Forum: Beyond the Atlantic." William and Mary Quarterly vol. 63, no. 4 (2006): 675-776.

Gárate Ojanguren, Monserrat. Comercio ultramarino e Ilustración. La Real Compañía de la Habana. San Sebastian: Departamento de Cultura del País Vasco, 1993. 
García, Gloria. "El mercado de fuerza de trabajo en Cuba: El mercado esclavista (1760-1789)." In La esclavitud en Cuba, 124-148. Havana: Instituto de Ciencias Históricas, Editorial Academia, 1986.

Geggus, David. "The Arming of Slaves in the Haitian Revolution." In Arming Slaves from Classical Times to the Modern Age, edited by Christopher Leslie Brown and Philip D. Morgan, 209-232. New Haven and London: Yale University Press, 2006.

Gelderblom, Oscar, Abe de Jong and Joost Jonker. "An Admiralty for Asia: Isaac le Maire and Conflicting Conceptions about the Corporate Governance of the VOC." Working paper, Erasmus Research Institute of Management, 2010.

Gentles, Ian. New Model Army in England, Scotland, and Ireland, 1645-1653. Cambridge, MA: Blackwell, 1994.

"Why Men Fought in the British Civil Wars," History Teacher vol. 26, no. 4 (1993): 407-418.

Gilroy, Paul. The Black Atlantic: Modernity and Double-Consciousness. Cambridge: Harvard University Press, 1993.

Glete, Jan. "Volume 1." Navies and Nations: Warships, Navies and State Building in Europe and America, 1500-1860, 2 Volumes. Stockholm: Almqvist \& Wiksell International, 1993.

Gomez, Michael. Exchanging our Country Marks: The Transformation of African Culture in the Antebellum South. Chapel Hill: University of North Carolina Press, 1998.

Goodman, David C. Spanish Naval Power 1589-1665: Reconstruction and Defeat. Cambridge and New York: Cambridge University Press, 1997.

Goslinga, Cornelis. The Dutch in the Caribbean and on the Wild Coast 1580-1680. Assen: Van Gorcum, 1971.

- The Dutch in the Caribbean and in the Guianas, 1680-1791, Anjerpublikaties 19. Assen, NL: Van Gorcum, 1985.

Gould, Eliga. "Entangled Histories, Entangled Worlds: The English-Speaking Atlantic as a Spanish Periphery." American Historical Review vol. 112, no. 3 (2007): 764-786.

Gragg, Larry. “To Procure Negros': The English Slave Trade to Barbados, 1627-166o." Slavery \& Abolition vol. 16, no. 1 (1995): 65-84.

Greene, Jack. "Beyond Power: Paradigm Subversion and Reformulation and the Re-Creation of the Early Modern Atlantic World." In Interpreting Early America: Historiographical Essays, edited by Jack Greene, 17-42. Charlottesville: University Press of Virginia, 1996.

- "Hemispheric History and Atlantic History." In Atlantic History: A Critical Appraisal, edited by Jack Greene and Phillip Morgan, 299-317. New York: Oxford University Press, 2009.

Griffiths, Paul. "Masterless Young People in Norwich, 1560-1645." In The Experience of Authority in Early Modern England, edited by Paul Griffiths, Adam Fox \& Steve Hindle, 146-186. New York: St. Martin's Press, 1996. 
Gross, Sue Anderson. "Labor in Amazonia in the first half of the eighteenth century," The Americas vol. 32, no. 2 (1975): 211-221.

Grubb, Farley. "Fatherless and Friendless: Factors Influencing the Flow of English Emigrant Servants." Journal of Economic History vol. 52, no. 1 (1992): 85-108.

_. "The Transatlantic Market for British Convict Labor." The Journal of Economic History. vol. 6o, no. 1 (2000): 94-122.

- "The Market Evaluation of Criminality: Evidence from the Auction of British Convict Labor in America, 1767-1775." The American Economic Review vol. 91, no. 1 (2001): 295-304.

Gwynn, Aubrey. “Cromwell's Policy of Transportation, Part I.” Studies: An Irish Quarterly Review of Letters, Philosophy \& Science vol. 19 (1930): 607-623.

Hamilton, Marsha. Social and Economic Networks in Early Massachusetts: Atlantic Connections. State College: Pennsylvania State University Press, 2009.

Handler, Jerome. "Slave Revolts and Conspiracies in Seventeenth-Century Barbados." New West Indian Guide Vol. $5^{6}$ (1982): $5^{-43}$.

Hanson, Lee and Dick Ping Hsu. Casemates and Cannonballs: Archeological Investigations at Fort Stanwix, Rome, New York. Washington, DC: U.S. Department of the Interior, National Park Service, 1975.

Hindle, Steve. On the Parish? The Micro-Politics of Poor Relief in Rural England c. 15501750. Oxford: Oxford University Press, 2004.

—. "Waste' Children? Pauper Apprenticeship under the Elizabethan Poor Laws." In Women, Work, and Wages in England, 1600-1850, edited by Penelope Lane and Neil Raven. Woodbridge, Suffolk: Boydell Press, 2004.

Holt, Thomas. The Problem of Freedom: Race, Labor, and Politics in Jamaica and Britain, 1832-1938. Baltimore: Johns Hopkins Press, 1992.

Hoogbergen, Wim S.M. The Boni Maroon Wars in Suriname. Leiden; New York: Brill, 1990.

Inikori, Joseph E. Africans and the Industrial Revolution in England: A Study in International Trade and Economic Development. New York: Cambridge, 2002.

Inikori, Joseph E. and Stanley L. Engerman, eds., The Atlantic Slave Trade: Effects on Economics, Society, and Peoples in Africa, the Americas, and Europe. Durham, N.C.: Duke University Press, 1992.

Israel, Jonathan. The Dutch Republic and the Hispanic World 1606-1661. Oxford: Clarendon Press, 1982.

- "England, the Dutch Republic, and Europe in the Seventeenth Century." Historical Journal, vol. 4, no. 2 (1997): 1117-1121.

Jennings, Evelyn P. "War as the Forcing House of Change," William and Mary Quarterly 3rd Series, vol. 63, no. 3 (2005): 411-440.

_ . "Paths to Freedom: Imperial Defense and Manumission in Havana, 1762-1800," In Paths to Freedom: Manumission in the Atlantic World, edited by Rosemary 
Brana-Shute and Randy J. Sparks, 121-141. Columbia, SC: University of South Carolina Press, 2009.

- "Some Unhappy Indians Trafficked by Force': Race, Status and Work Discipline in mid-Nineteenth Century Cuba," In Bonded Labor in the Cultural Contact Zone, edited by Gesa Mackenthun and Raphael Hörmann, 209-225. Münster and New York: Waxmann, 2010.

Johnson, Robert C. "The Transportation of Vagrant Children from London to Virginia, 1618-22." In Early Stuart Studies: Essays in Honor of David Harris Willson, edited by Howard S. Reinmuth Jr. Minneapolis: University of Minnesota Press, 1970.

Johnson, Walter. Soul by Soul: Life Inside the Antebellum Slave Market. Cambridge, MA: Harvard University Press, 1999.

- "The Pedastal and the Veil: Rethinking the Capitalism/Slavery Question." Journal of the Early Republic vol. 24, no. 2 (2004): 299-308.

Johnston, A.J.B. Control and Order in French Colonial Louisbourg, 1713-1758. Lansing: Michigan State University Press, 2001.

Jones, J.R. The Anglo-Dutch Wars of the Seventeenth Century. New York: Longman, 1996. Jones, Whitney R.D. Thomas Rainborowe: Civil War Seamen, Siegemaster, and Radical. Woodbridge, UK: Boydell Press, 2005.

Jordan, Don and Michael Walsh. White Cargo: The Forgotten History of Britain's White Slaves in America. New York: New York University Press, 2008.

Jung, Moon-Ho. Coolies and Cane: Race, Labor and Sugar in the Age of Emancipation. Baltimore: Johns Hopkins Press, 2006.

Klein, Herbert S. "The Atlantic Slave Trade to 1650." In Tropical Babylons: Sugar and the

Making of the Atlantic World, 1450-1680, edited by Stuart Schwartz. Chapel Hill: University of North Carolina Press, 2005.

Klooster, Wim. Illicit Riches: The Dutch Trade in the Caribbean, 1648-1795. Leiden: Brill, 1995 .

_. "The Place of New Netherland in the West India Company's Grand Scheme." In Revisiting New Netherland: Perspectives on Early Dutch America, edited by Joyce D. Goodfriend, 57-70. Leiden/Boston: Brill, 2005.

- Revolutions in the Atlantic World: A Comparative History. New York: New York University Press, 2009.

— . "Het begin van de Nederlandse slavenhandel in het Atlantisch gebied." In Alle Strekenvan Het Kompas. Maritieme geschiedenis is Nederland, 249-262, edited by Maurits Ebben, Henk den Heijer and Joost Schokkenbroek. Zutphen: Walburg Pers, 2010.

Koot, Christian J. "A 'Dangerous Principle': Free Trade Discourses in Barbados and the English Leeward Islands, 1650-1689." Early American Studies: an Interdisciplinary Journal vol. 5, no.1 (2007): 132-63.

- Empire at the Periphery: British Colonists, Anglo-Dutch Trade, and the Development of the British Atlantic, 1621-1713. New York: New York University Press, 2011. 
Kotowski, Peter. “The Best Poor Man's Country?': Indentured Servitude in Pennsylvania, 1681-1776." Ph.D. Dissertation: Loyola University Chicago, forthcoming 2015.

Kruijtzer, Gijs. "European Migration in the Dutch Sphere." In Dutch Colonialism, Migration and Cultural Heritage, edited by Gert Oostindie, 97-154. Leiden: KITLV Press, 2008.

Kuethe, Allan J. Cuba, 1753-1815: Crown, Military and Society. Knoxville: University of Tennessee Press, 1986.

Kupperman, Karen Ordahl. "Errand into the Indies: Puritan Colonization from Providence Island through the Western Design." William and Mary Quarterly vol. 45, no. 2 (1988): 70-99.

Kwon, Roy. "Hegemonies in the World-System: An Empirical Assessment of Hegemonic Sequences from the 16th to 2oth Century." Sociological Perspectives vol. 54, no. 4 (2011): 593-617.

La Rosa Corzo, Gabino. Los cimarrones de Cuba. Havana: Editorial de Ciencias Sociales, 1988.

Lai, Walton Look. Indentured Labor, Caribbean Sugar: Chinese and Indian Migrants to The British West Indies, 1838-1918. Baltimore: Johns Hopkins University Press, 1993.

Landers, Jane. Fort Mose Gracia Real De Santa Teresa De Mose: A Free Black Town in Spanish Colonial Florida. St. Augustine: St. Augustine Historical Society, 1992.

_. Black Society in Spanish Florida. Champaign: University of Illinois Press, 1999. - Atlantic Creoles in the Age of Revolutions. Cambridge MA and London: Harvard University Press, 2010.

Las Casas, Bartolomé de. An Account, Much Abbreviated, of the Destruction of the Indies. Edited with and introduction by Franklin W. Knight. Translated by Andrew Hurley. Indianapolis and Cambridge: Hackett Publishing Co., 2003.

Légier, Emile. La Martinique et la Guadeloupe. Paris: Bureaux de la Sucrerie Indigène et Coloniale, 1905.

Leng, Thomas. "Commercial Conflict and Regulation in the Discourse of Trade in Seventeenth-Century England." The Historical Journal vol. 48, no. 4 (2005): 933-954.

Lenihan, Pa'draig. "War and Population, 1649-52." Irish Economic and Social History vol. 24 (1997): 1-21.

Liberalli Belotto, Heloísa. "Política indigenista no Brasil colonial, 1570-1750," Revista do Instituto de Estudos Brasileiros vol. 29 (1988): 49-6o.

Lichtenstein, Alex. Twice the Work of Free Labor: The Political Economy of Convict Labor in the New South. New York: Verso, 1996.

Linebaugh, Peter and Marcus Rediker. The Many-Headed Hydra: Sailors, Slaves, Commoners, and the Hidden History of the Revolutionary Atlantic. Boston: Beacon Press, 2000. 
. "The Many-Headed Hydra: Reflections on History from Below." In Beyond Marx: Theorizing Global Labor Relations in the Twenty-First Century, edited by Marcel van der Linden and Karl Roth, 21-40. Leiden: Brill, 2014.

Lisboa, João Francisco. Crônica do Brasil colonial: apontamentos para a história do Maranhão. Petrópolis/Brasília: Vozes/INL, 1976.

Livi-Bacci, Maximo. "The Depopulation of Hispanic America after the Conquest," Population and Development Review vol. 32, no. 2 (2006): 199-232.

Lockhart, James. Spanish Peru 1532-156o. A Colonial Society. Madison: University of Wisconsin Press 1968.

Lockhart, James and Stuart B. Schwartz. Early Latin America. Cambridge and New York: Cambridge University Press, 1983.

López Estrada, Francisco and María Teresa López García-Berdoy, eds. Las Siete Partidas Antología. Madrid: Editorial Castalia, 1992.

Lovejoy, Paul E. Slavery, Commerce and Production in the Sokoto Caliphate of West Africa. Trenton, N.J.: Africa World Press, 2005.

Lovejoy, Paul E. and Nicholas Rogers, eds. Unfree Labour in the Development of the Atlantic World. Ilford, UK and Portland, OR: Frank Cass, 1994.

Lucassen, Jan and Marcel van der Linden. Prolegomena for a Global Labor History. Amsterdam: International Institute for Social History, 1999.

Luzader, John F. The Construction and Military History of Fort Stanwix. Washington: Office of Park Historic Preservation, National Park Service, 1969.

Makepeace, Margaret. "English Traders on the Guinea Coast, 1657-1688: An Analysis of the East India Company Archive." History in Africa vol. 16 (1989): 237-284.

Mancke, Elizabeth. "Empire and State." The British Atlantic World, 1500-180o, edited by David Armitage and Michael Braddick, 175-195. New York: Palgrave MacMillan, 2002.

Mancke, Elizabeth and Carole Shammas. The Creation of the British Atlantic World. Baltimore: Johns Hopkins University Press, 2005.

Manning, Patrick. Slavery, Colonialism, and Economic Growth in Dahomey, 1640-1960. Cambridge: Cambridge University Press, 1982.

- Slavery and African Life: Occidental, Oriental, and African Slave Trades. Cambridge University Press, 1990.

- (ed.). Slave Trades, 1500-1800: The Globalization of Forced Labour. Aldershot: Variorum, 1996.

- The African Diaspora: A History through Culture. New York: Columbia University Press, 2009.

Manucy, Albert and Luis Arana. The Building of the Castillo de San Marcos. St. Augustine: Eastern National Park and Monument Association, 1977.

Marrero, Levi. Cuba, economía y sociedad. 15 vols. Madrid: Playor, 1972-1992. 
Martínez-Fernández, Luis. "The Havana Anglo-Spanish Mixed Commission for the Suppression of the Slave Trade and Cuba's Emancipados." Slavery \& Abolition vol. 16, no. 2 (1995): 209-213.

Mártires Coelho, Geraldo. "A pátria do Anticristo: A expulsão dos jesuítas do Maranhão e Grão-Pará e o messianismo milenarista do Padre Vieira”, Luso-Brazilian Review vol. 37, no. 1 (2000): 17-32.

Mello, Márcia. Fé e império: as Juntas das Missões nas conquistas portuguesas. Manaus: EdUA, 2009.

Menard, Russell. Sweet Negotiations: Sugar, Slavery, and Plantation Agriculture in Early Barbados. Charlottesville: University of Virginia Press, 2006.

"Plantation Empire: How Sugar and Tobacco Planters Built Their Industries and Raised an Empire." Agricultural History vol. 81, no. 3 (2007): 309-332.

Mendez Capote, Renée. Fortalezas de la Habana colonial. Havana: Editorial Gente Nueva, 1974.

Meuwese, Mark. Brothers in Arms, Partners in Trade: Dutch-Indigenous Alliances in the Atlantic World, 1595-1674. Leiden/Boston: Brill, 2012.

Miller, Joseph C. Way of Death:Merchant Capitalism and the Angolan Slave Trade, 1730-1830. Madison: University of Wisconsin Press, 1988.

Mintz, Sidney. "Creolization and Hispanic Exceptionalism." Review (Fernand Braudel Center) vol. 31, no. 3 (2008): 251-265.

Mintz, Sidney, Dale Tomich, Michael Zeuske, et al. "The So-Called World System: Local Initiative and Local Response." Dialectical Anthropology, vol. 2 (1977): 253-267.

- Sweetness and Power: The Place of Sugar in Modern History. New York: Penguin, 1986.

- "The Second Slavery: Mass Slavery, World-Economy, and Comparative Microhistories." Review (Fernand Braudel Center) vol. 31, nos. 2-3 (2008): Part I, 91-247; Part II, 254-437.

Monteiro, John M. "Armas e armadilhas: história e resistência dos índios," In A Outra Margem do Ocidente, edited by Adauto Novaes, 237-256. São Paulo: FUNARTE/ Companhia das Letras, 1999.

Moreno Fraginals, Manuel. El ingenio. Complejo económico social cubano del azúcar. Barcelona: Editorial Crítica, 2001.

Morgan, Edmund S. American Slavery, American Freedom: The Ordeal of Colonial Virginia. New York: Norton, 1975.

Morgan, Philip. "Africa and the Atlantic." In Atlantic History: A Critical Appraisal, edited by Jack Greene and Phillip Morgan, 223-248. New York: Oxford University Press, 2009. Moyano Bazzini, Eduardo L. La nueva frontera del azúcar. El ferrocarril y la economía cubana del Siglo XIX. Madrid: Consejo Superior de Investigación, 1991.

Munford, Clarence. The Black Ordeal of Slavery and Slave Trading in the French West Indies, 1625-1715, 2 vols. Lewiston, NY: Edwin Mellen Press, 1992. 
Murray, David. Odious Commerce. Britain, Spain and the Abolition of the Cuban Slave Trade. Cambridge: Cambridge University Press, 1981.

Nadal y Oller, Jorge. La población española (Siglos XVI a XX). Barcelona: Ediciones Ariel, 1966.

Naranjo Orovio, Consuelo. "La amenaza haitiana, un miedo interesado. Poder y fomento de la población blanca en Cuba." In El rumor de Haití en Cuba. Temor, raza, y rebeldía, 1789-1844, edited by María Dolores González-Ripoll, Consuelo Naranjo Orovio, Ada Ferrer, Gloria García and Josef Opatrný, 83-178. Madrid: Consejo Superior de Investigaciones Científicas, 2004.

Newman, Simon. A New World of Labor: The Development of Plantation Slavery in the British Atlantic. Philadelphia: University of Pennsylvania Press, 2013.

Newton, Arthur Percival. The Colonizing Activities of the English Puritans. New Haven: Yale University Press, 1914.

Northrup, David. Indentured Labor in the Age of Imperialism, 1834-1922. Cambridge: Cambridge University Press, 1995.

- "Indentured Indians in the French Antilles," RFHOM vol. 87 , no. $3^{26-327}$ (2000): 245-271.

Ó Siochrú, Micheál. Oliver Cromwell and the Conquest of Ireland. London: Faber and Faber, 2008.

Oostindie, Gert and Jessica Vance Roitman. "Repositioning the Dutch in the Atlantic, 1680-180o." Itinerario vol. 36, no. 2 (2012): 129-16o.

Ormrod, David. The Rise of Commercial Empires: England and the Netherlands in the Age of Mercantilism, 1650-1770. New York: Cambridge University Press, 2003.

Paesie, Rudolf. Lorrendrayen op Africa. De Illegale Goederen- en Slavenhandel op WestAfrika Tijdens het Achttiende-eeuwse Handelsmonopolie van de West-Indische Compagnie, 1700-1734. Amsterdam: De Bataafsche Leeuw, 2008.

Pagden, Anthony. Lords of All the World: Ideologies of Empire in Spain, Britain and France, c. 1500-c.180o. New Haven, Conn.: Yale University Press, 1995.

Palmer, Colin A., ed. The Worlds of Unfree Labour: From Indentured Servitude to Slavery. Aldershot: Ashgate Variorum, 1998.

Paquette, Robert L. Sugar Is Made with Blood. Middletown, CT: Wesleyan University Press, 1988.

Peabody, Sue and Keila Grinberg. Slavery, Freedom, and the Law in the Atlantic World: A Brief History with Documents. Boston: Bedford/St. Martin's, 2007.

Pereira Caetano, Antônio Filipe. Entre drogas e cachaça: A política colonial e as tensões na América portuguesa 1640-1710). Macieó: EdUFAL, 2009.

Pérez Louis A.Jr. To Die in Cuba: Suicide and Society. Chapel Hill and London: University of North Carolina Press, 2005.

- Cuba. Between Reform and Revolution 3rd ed. New York and Oxford: Oxford University Press, 2006. 
Pérez, Yolanda Rodríguez. "Wijze Indianen, Barbaarse Hollanders. De beeldvorming van Nederlanders en Indianen in de Spaanse literatuur van de Gouden Eeuw." De Zeventiende Eeuw vol. 21, no. 1 (2005): 99-111.

Pérez-Mallaína, Pablo E. Spain's Men of the Sea: Daily Life in the Indies Fleets in the Sixteenth Century. Translated by Carla Rahn Phillips. Baltimore and London: Johns Hopkins University Press, 1998.

Perrone-Moisés, Beatriz. "Índios livres e índios escravos. Os princípios da legislação indigenista colonial ( séculos XVI a XVIII)," in História dos índios no Brasil, edited by Manuela Carneiro da Cunha, 115-132. São Paulo: Companhia das Letras, 1992.

—. "Inventário da legislação indigenista. 1500-180o." In História dos índios no Brasil, edited by Manuela Carneiro da Cunha, 529-566. São Paulo: Companhia das Letras, 1992.

Pestana, Carla Gardina. The English Atlantic in an Age of Revolution, 1640-1661. Cambridge, MA: Harvard University Press, 2004.

Phillips, Carla Rahn. Six Galleons for the King of Spain. Baltimore: Johns Hopkins University Press, 1986.

"The Labour Market for Sailors in Spain." In "Those Emblems of Hell"? European Sailors and the Maritime Labour Market, 1570-1870, Research in Maritime History, no. 13, edited by Paul van Royen, Jaap Bruijn and Jan Lucassen. St. John's, Newfoundland: International Maritime Economic History Association, 1997.

Phillips, William D. "The Old World Background of Slavery in the Americas." In Slavery and the Rise of the Atlantic System, edited by Barbara L. Solow, 43-61. Cambridge: Cambridge University Press, 1991.

- Slavery in Medieval and Early Modern Iberia. Philadelphia, University of Pennsylvania Press, 2014.

Pietschmann, Horst. ed., Atlantic History: History of the Atlantic System, 1580-1830. Gottingen: Vandenhoeck and Ruprecht, 2002.

Pike, Ruth. Penal Servitude in Early Modern Spain. Madison: University of Wisconsin Press, 1983 .

Pike, Ruth "Penal Servitude in the Spanish Empire: Presidio Labor in the Eighteenth Century." Hispanic American Historical Review vol. 58, no. 1 (1978): 21-40.

Pincus, Stephen. Ideologies and the Making of English Foreign Policy, 1650-1658. Cambridge: Cambridge University Press, 1996.

Pocock, J.G.A. "Propriety, Liberty and Valor: Ideology, Rhetoric and Speech in the 1628 Debates in the House of Commons." In The Political Imagination in History: Essays Concerning J.G.A. Pocock, edited by D.N. DeLuna, Perry Anderson, and Glenn Burgess. Dexter, MI: Owlworks Press, 2006.

Postma, Johannes Menne. The Dutch in the Atlantic Slave Trade 1600-1815. Cambridge: Cambridge University Press, 1990. 
Postma, Johannes. "Suriname and Its Atlantic Connections, 1667-1795." In Riches from Atlantic Commerce: Dutch Transatlantic Trade and Shipping, 1585-1817, edited by Johannes Postma and Victor Enthoven, 287-322. Leiden: Brill Academic Publishers, 2003 .

Pound, John. Poverty and Vagrancy in Tudor England, 2nd ed. London: Longman, 1986.

Prak, Maarten. The Dutch Republic in the Seventeenth Century (Cambridge: Cambridge University Press, 2005.

Rabb, Theodore K. Jacobean Gentleman: Sir Edwin Sandys, 1561-1629. Princeton: Princeton University Press, 1998.

Rediker, Marcus. Between the Devil and the Deep Blue Sea: Merchant Seamen, Pirates, and the Anglo-American World, 1700-1750. New York: Cambridge University Press, 1987.

— . "The Red Atlantic, or, 'A Terrible Blast Swept over the Heaving Sea." In Sea Changes: Historicizing the Ocean, edited by Bernhard Klein and Gesa Mackenthun. New York: Routledge, 2003.

. Villains of All Nations: Atlantic Pirates in the Golden Age. Boston: Beacon Press, 2005 .

. The Slave Ship: A Human History. Boston: Beacon Press, 2007.

Renard, Rosamund. "Labour Relations in Martinique and Guadeloupe, 1848-1870." In Caribbean Freedom, edited by Hilary Beckles and Verene Shepard. Kingston: Ian Randle, 1993.

Ribeiro da Silva, Francisco "A legislação seiscentista portuguesa e os índios do Brasil." In Brasil: colonização e escravidão, edited by Maria Beatriz Nizza da Silva, 15-27. Rio de Janeiro: Nova Fronteira, 2000.

Ribeiro de Moura Zeron, Carlos Alberto. Linha de fé: a Companhia de Jesus e a escravidão no processo de formação da sociedade colonial (Brasil, séculos XVI e XVII). São Paulo: Editora da Universidade de São Paulo, 2011.

Rockman, Seth. "The Unfree Origins of American Capitalism." In The Economy of Early America: Historical Perspectives \& New Directions, edited by Cathy Matson, 335-362. College Park, PA: Pennsylvania State University Press, 2006.

Rodney, Walter. A History of the Guyanese Working People, 1881-1905. Baltimore: Johns Hopkins Press, 1981.

Rogers, Nini. Ireland, Slavery and Anti-Slavery. New York: Palgrave, 2001.

Roldán de Montaud, Inés. "Origen, evolución, y supresión del grupo de negros 'emancipados' en Cuba 1817-1870." Revista de Indias vol. 42, nos. 169-170 (1982): 574-76.

Roopnarine, Lomarsh. Indo-Caribbean Indenture: Resistance and Accommodation, 1838-1920. Mona, JA: University of the West Indies Press, 2007.

Rupert, Linda Marguerite. Creolization and Contraband: Curaçao in the Early Modern Atlantic World. Athens: University of Georgia Press, 2012. 
Sainton, Jean-Pierre. Les Nègres en Politique: Couleur, Identités, et Strategies de Pouvoir en Guadeloupe au Tournant du Siècle, 2 vols. Paris: Septentrion Presses Universitaires, 2000.

Santos, Francisco J. Andrés "Encomienda y usufructo en Indias," Legal History vol. 69, nos. $3 / 4$ (2001): $245^{-248 .}$

Schloss, Rebecca Hartkopf. Sweet Liberty: The Final Days of Slavery in Martinique. Philadelphia: University of Pennsylvania Press, 2009.

Schmidt, Benjamin. 'Exotic allies. The Dutch-Chilean Encounter and the Failed Conquest of America." Renaissance Quarterly vol. $5^{2}$ (1999): 440-473.

Schmidt, Nelly. "1848 dans les Colonies Françaises des Caraïbes: Ambitions Républicaines et Ordre Colonial." RFHOM vol. 87, nos. 326-327 (2000): 205-244.

Schmidt-Nowara, Christopher. Empire and Antislavery. Spain, Cuba, and Puerto Rico, 1833-1874. Pittsburgh: Pittsburgh University Press, 1999.

Schnakenbourg, Christian. "From Sugar Estate to Central Factory." In Crisis and Change in the International Sugar Economy, 1850-1914, edited by Bill Albert and Adrian Graves. Norwich: ISC Press, 1984.

- Histoire de l'Industrie Sucrière en Guadeloupe aux XIXe et XXe Siècles: La Transition Post-Esclavagiste 1848-1883. Paris: Harmattan, 2007.

Schutte, Gerrit Jan. Patriotten De Nederlandse en de Koloniën. Een Onderzoek Naar hun Denkbeelden en Optreden, 1770-180o. Utrecht: Rijksuniversiteit Utrecht, 1974.

Schwartz, Stuart. Sugar Plantation in the Formation of Brazilian Society. New York: Cambridge, 1985 .

Scott, Jonathan. "What Were Commonwealth Principles?" Historical Journal vol. 47, no. 3 (2004): 591-613.

Sewell, Jr., William H. A Rhetoric of Bourgeois Revolution: The Abbé Sieyes and What is the Third Estate. Durham: Duke University Press, 1994.

Sharpe, J.A. Crime in Early Modern England 1550-1750. London: Longman, 1984.

Shepherd, Verene. Livestock, Sugar, and Slavery: Contested Terrain in Colonial Jamaica. Kingston, JA: Ian Randle, 2009.

Sheppard, Jill. The "Redlegs" of Barbados: Their Origins and History, Millwood, N.Y.: KTO Press, 1977.

Sheridan, Richard B. Sugar and Slavery: An Economic History of the British West Indies, 1623-1775. Kingston: Canoe Press, 2000.

Sidbury, James. Becoming African in America: Race and Nation in the Early Black Atlantic. New York, Oxford University Press, 2007.

Sidbury, James, Jorge Cañizares-Esguerra, James Sweet, Claudio Saunt, Pekka Hämäläinen, Laurent Dubois, Christopher Hodson, Karen Graubart, Patrick Griffin. "Forum: Ethnogenesis." William and Mary Quarterly, vol. 68, no. 2 (2011): 181-239.

Silva, Alfonso Franco. La esclavitud en Andalucía, 1450-1550. Granada: Universidad de Granada, 1990. 
Skinner, Quentin. "John Milton and the Politics of Slavery." In Quentin Skinner, Visions of Politics: Renaissance Virtues, 3 vols. Cambridge: Cambridge University Press, (2002): 2: 286-308.

Sklansky, Jeff. "The Elusive Sovereign: New Intellectual and Social Histories of Capitalism." Modern Intellectual History vol. 9, no. 1 (2012): 233-248.

Skocpol, Theda. "Wallerstein's World Capitalist System: A Theoretical and Historical Critique." American Journal of Sociology vol. 82, no. 5 (1977): 1075-109o.

Slack, Paul. Poverty and Policy in Tudor and Stuart England. London: Longman, 1988.

- The English Poor Law, 1531-1782 (Cambridge: Cambridge University Press, 1995. . From Reformation to Improvement: Public Welfare in Early Modern England. Oxford: Clarendon Press, 1998.

Slicher Van Bath, B.H. "The Absence of White Contract Labour in Spanish America during the Colonial Period, " In Colonialism and Migration: Indentured Labour Before and After Slavery, edited by P.C. Emmer, 19-31. Dordrecht: Martinus Nijhoff Publishers, 1986.

Smallwood, Stephanie. Saltwater Slavery: A Middle Passage from Africa to American Diaspora. Cambridge: Harvard University Press, 2007.

Smith, Abbot Emerson. "The Transportation of Convicts to the American Colonies in the Seventeenth Century," American Historical Review vol. 39, no. 2 (1934): 232-249.

- Colonists in Bondage: White Servitude and Convict Labor in America, 1607-1776. Chapel Hill: University of North Carolina Press, 1947.

Solow, Barbara, ed., Slavery and the Rise of the Atlantic System. New York: Cambridge University Press, 1991.

Souden, David. “Rogues, Whores and Vagabonds'? Indentured Servant Emigrants to North America, and the Case of Mid-Seventeenth-Century Bristol." Social History, vol. 3, no. 1 (1978): 23-41.

Staarman, Alfred. "De VOC en de Staten-Generaal in de Engelse Oorlogen: Een Ongemakkelijk Bondgenootschap." Tïdschrift voor Zeegeschiedenis vol. 15, no. 1 (1996): 3-24.

Steele, Ian K. "Bernard Bailyn's American Atlantic." History and Theory vol. 46, no. 1 (2007): 48-58.

Steensgaard, Niels. Carracks, Caravans and Companies: The Structural Crisis in the European- Asian Trade in the Early 17th Century. Copenhagen: Lund, 1973.

Stella, Alessandro. Histoires d'esclaves dans la péninsule ibérique. Paris: École des Hautes Études en Sciences Sociales, 2000.

Stern, Steve J. "Feudalism, Capitalism, and the World System in the Perspective of Latin America and the Caribbean." American Historical Review vol. 93, no. 4 (1988): $829-872$.

Sweet, David. "A rich realm of nature destroyed: the middle Amazon valley, 1640-1750." PhD diss., University of Wisconsin, Madison, 1974. 
te Brake, Wayne, and Wim Klooster. "Introduction." In Power and the City in the Netherlandic World, edited by Wayne te Brake and Wim Klooster, 1-11. Leiden: Brill, 2006.

Tepaske, John Jay. The Governorship of Spanish Florida. Durham: Duke University Press, 1964.

Thornton, John. Africa and Africans in the Making of the Atlantic World, 1400-1600. New York: Cambridge University Press, 1992.

Tilly, Charles. Coercion, Capital, and European states, AD 990-1992. Cambridge, MA: Blackwell, 1992.

Tomich, Dale. Slavery in the Circuit of Sugar: Martinique in the World Economy, 18301848. Baltimore: Johns Hopkins University, 1990.

—. "World Slavery and Caribbean Capitalism: Cuban Sugar and Slavery." Theory and Society vol. 23, no. 1 (1991): 297-319.

- Through the Prism of Slavery: Labor, Capital, and the World Economy. Lanham: Rowman \& Littlefield: 2004.

Trautmann, Thomas. Aryans and British India. Berkeley: University of California Press, 1997.

Vainfas, Ronaldo. Ideologia e escravidão: os letrados e a sociedade escravista no Brasil colonial. Petrópolis: Vozes, 1986.

van Alphen, G. Jan Reeps en Zijn Onbekende Kolonisatiepoging in Zuid-Amerika, 1692. Assen: Van Gorcum, 1960.

van den Boogaart, E. and P. Emmer, "Colonialism and Migration: an overview," In Colonialism and Migration: Indentured Labour Before and After Slavery, edited by P.C. Emmer, 3-15. Dordrecht: Martinus Nijhoff Publisher, 1986.

van der Linden, Marcel. Transnational Labour History: Explorations. Aldershot: Ashgate Variorum, 2003.

Workers of the World: Essays Toward a Global Labor History. Leiden: Brill, 2008. van der Meiden, G.W. Betwist Bestuur: Een eeuw Strijd om de Macht in Suriname, 16511753. Amsterdam: Bataafsche Leeuw, 2008.

van Groesen, Michiel. "Lessons Learned: The Second Dutch Conquest of Brazil and the Memory of the First." Colonial Latin American Review vol. 20, no. 2 (2011): 167-193.

van Hoboken, W.J. Witte de With in Brazilië, 1648-1649. Amsterdam, 1955.

van Ittersum, Martine Julia. "The Long Goodbye: Hugo Grotius' Justification of Dutch Expansion Overseas, 1615-1645." History of European Ideas vol. 36 (2010): 386-411.

Verlinden, Charles. L'esclavage dans l'Europe médiévale, tome 1, Péninsule ibériqueFrance. Brugge: De Tempel, 1955.

Wallerstein, Immanuel, The Modern World-System: Capitalist Agriculture and the Origins of the European World-Economy in the Sixteenth Century. New York:Academic Press, 1976. 
. The Modern World-System II: Mercantilism and the Consolidation of the European World-Economy, 16oo-1750. New York: Academic Press, 1980.

- The Modern World-System III: The Second Era of Great Expansion of the Capitalist World-Economy, 1730-1840s. San Diego, CA: Academic Press, 1989.

- The Modern, IV: Centrist Liberalism Triumphant, 1789-1914. Berkeley, CA: University of California Press, 2011.

- "The West, Capitalism, and the Modern World-System." Review (Fernand Braudel Center) vol. 15 (1992): 561-595.

Wareing, John. "Violently taken away or cheatingly duckoyed'. The Illicit Recruitment in London of Indentured Servants for the American Colonies, 1645-1718." The London Journal: A Review of Metropolitan Society Past and Present vol. 26 (2001):1-22.

- . "Preventive and Punitive Regulation in Seventeenth-Century Social Policy: Conflicts of Interest and the Failure to Make 'stealing and transporting Children, and other Persons' a Felony, 1645-73." Social History vol. 27, no. 3 (2002): 288-308.

Way, Peter. "Class Warfare: Primitive Accumulation, Military Revolution and the British

War Worker." In Beyond Marx: Confronting Labor History and the Concept of Labor with the Global Labor Relations of the 2ist Century, edited by Marcel van der Linden and Karl Heinz Roth. Berlin and Hamburg: Assoziation A, 2009.

_ . "Memoirs of an Invalid: James Miller and the Making of the British-American Empire in the Seven Years' War." In Rethinking U.S. Labor History: Essays in the Working-Class Experience, 1756-20o9, 25-56, edited by Donna Haverty-Stacke and Daniel J. Walkowitz. New York: Bloomsbury Academic, 2010.

—. "Black Service ... White Money': The Peculiar Institution of Military Labor in the British Army during the Seven Years' War." In Workers Across the Americas: The Transnational Turn in Labor History, edited by Leon Fink, 57-80. New York: Oxford University Press, 2011.

Weber, David J. Bárbaros. Spaniards and Their Savages in the Age of Enlightenment. New Haven and London: Yale University Press, 2005.

Weststeijn, Arthur. "Republican Empire. Colonialism, Commerce and Corruption in the Dutch Golden Age." Renaissance Studies vol. 26, no. 4 (2012): 491-509.

Wheat, David. "Mediterranean Slavery, New World Transformations: Galley Slaves in the Spanish Caribbean, 1578-1635." Slavery \& Abolition vol. 31, no. 3 (September 2010): 328-333.

Wilder, Gary. The French Imperial Nation-State: Negritude and Colonial Humanism Between the Two World Wars. Chicago: University of Chicago Press, 2005.

Williams, Eric. Capitalism and Slavery. Chapel Hill: University of North Carolina Press, 1944.

Wojtalewicz, Paul. "The Junta de Missões/Junta de Misiones: a comparative study of peripheries and imperial administration in eighteenth-century Iberian empires," Colonial Latin America Review vol. 8, no. 2 (1999): 225-240. 
Wolbers, Julien. Geschiedenis van Suriname. Amsterdam: Emmering, 1970.

Woodbridge, Linda. Vagrancy, Homelessness, and English Renaissance Literature. Urbana: University of Illinois Press, 2001.

Worden, Blair. The Rump Parliament, 1648-1653. New York: Cambridge University Press, 1974.

Wright, Ernest. French Politics in the West Indies. Ann Arbor: U. Microfilms International, 1981.

Wright, Irene. The Early History of Cuba, 1492-1586. New York: Macmillan, 1916.

Wrigley, E.A. and Schofield, R.S. The Population History of England, 1541-1871: A Reconstruction. New York: Cambridge University Press, 1981.

Yun, Lisa. The Coolie Speaks: Chinese Indentured Laborers and African Slaves in Cuba. Philadelphia: Temple University Press, 2008.

Zahedieh, Nuala. The Capital and the Colonies: London and the Atlantic Economy 166o170o. New York: Cambridge University Press, 2012.

Zanetti, Oscar and Alejandro García. Sugar and Railroads. A Cuban History, 1837-1959. Translated by Franklin W. Knight and Mary Todd. Chapel Hill: University of North Carolina Press, 1998. 